\title{
QUALITY OF HEALTH INFORMATION ON WEBSITES WITH THE GREATEST POTENTIAL TO INFLUENCE USERS IN THE CZECH REPUBLIC
}

\author{
JITKA RUSOVÁ \\ Faculty of Health Studies, University of Pardubice \\ Průmyslová 395, 53210 Pardubice - Černá za Bory, Czech Republic \\ E-mail address: jitka.rusova@upce.cz \\ ORCID: https://orcid.org/0000-0003-2246-1265 \\ ONDŘEJ PLESKOT \\ Faculty of Health Studies, University of Pardubice \\ Průmyslová 395, 53210 Pardubice - Černá za Bory, Czech Republic \\ E-mail address: ondrej.pleskot@upce.cz \\ ORCID: https://orcid.org/0000-0003-2168-8353
}

\begin{abstract}
Aim. The aim is to determine which websites most influenced Internet users in the Czech Republic in health matters, to assess the quality of these websites according to predetermined criteria, and to analyse the impact of the project MedLike.

Methods. The points assigned to individual websites displayed when searching 734 terms (diseases and symptoms) were summed up to obtain a list of the most viewed websites. The quality of the websites was assessed according to predetermined criteria.

Results. The websites with the greatest potential to influence Internet users in terms of health information (the most viewed websites) are ulekare.cz, mojezdravi.cz, cs.wikipedia.org. Most of them lack links to resources, information about the authors and dates of publication/updates. The articles are not easy to understand and contain unexplained medical terms. A vast majority of websites lacked updated information.

Conclusion. Incorrect, misleading, and not up-to-date information was found in the articles. This can lead to the harm to the user.

Key words: Internet, quality assessment criteria, online information, health information, health literacy
\end{abstract}

\section{INTRODUCTION}

Towadays, we are facing a critical issue of health literacy which has become survey. In this survey, the inhabitants of the Czech Republic were placed last

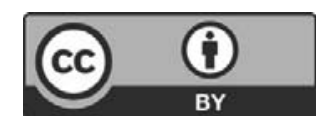


but one out of all EU countries as $59.4 \%$ out of 1,037 respondents manifested inadequate health literacy (Kučera, Pelikan, \& Šteflová, 2016). Health literacy implies skills essential to recognise the need to obtain information on medical topics, to identify appropriate sources, to search relevant information, to assess its quality and apply it to the situation, to analyse information, understand it, and use it appropriately to support health (Kučera, Pelikan, \& Šteflová, 2016; Lesenková, 2016).

Thus, the ability to obtain information is also related to the ability to assess its quality. Particularly, in the context of searching health information on the Internet, the quality of available information is crucial as the motivation of users searching health terms might not be just to educate themselves but also to verify information provided by health professionals, to make a selfdiagnosis or even question a diagnosis made by a physician (Diviani, van den Putte, Meppelink, \& van Weert, 2016; Turan, Kaya, \& Aydin, 2015). Both foreign and Czech authors point out the dubious quality of Internet sources (Impicciatore, Pandolfini, Casella, \& Bonati, 1997; Purcell, Wilson, \& Delamothe, 2002; Parvizi, Talai, \& Parvizi, 2017; Zhang, Sun, \& Xie, 2015; Pleskot, \& Rusová, 2018). Health professionals seek ways to make quality health information more accessible. On 7th April 2018, on the occasion of World Health Day, the National Medical Library (Czech Republic) launched a web portal called MedLike to promote health literacy for the general public (Lesenková, 2016; National Medical Library, 2018-2020; Maixnerová, Kř́̌ž, Mašková, Valdmanová, Lesenková, \& Burský, 2019). The question is how this endeavour will affect the researched issue of the availability of quality Internet resources.

\section{RESEARCH OBJECTIVES}

The survey aimed to determine the frequency of Internet searches for particular health topics (diseases, symptoms, drugs/medications, and herbs), which websites most influenced Internet users in the Czech Republic in health matters, to assess the quality of these websites according to predetermined criteria and to analyse the impact of the project of the National Medical Library (NML), the new web portal MedLike, dedicated to promoting health literacy among the general public.

\section{METHODOLOGY}

\section{Determining the Frequency of Searches for Particular Health Topics and the Most Viewed Websites}

Firstly, 7,753 terms related to health topics (illnesses, symptoms, drugs/ medications, and herbs) were selected. As Czech Internet users use predominantly Google Search and Seznam.cz (71\% and 25\% respectively) (TOPlist, 1997-2018; Cerná, \& Černý, 2011), we analysed the frequency of searches of the terms on both search engines within the year 2018. The list used in the 
survey is not standardised, however, the list must make allowances for various names for the same health problems (e.g. sore throat and laryngitis), spelling variants, and also commonly misspelt terms (e.g. "hemroids" for "hemorrhoids") to determine not only the frequency of searches but also which variant was more frequently searched. For the purposes of this article, the terms were analysed separately not to blur the distinctions individual terms show the interest of Internet users in a particular topic, but do not reveal the reasons for the search. In this survey, the topics mainly served as a means to determine the most viewed websites and to select specific articles to assess the quality of information available on Czech websites. For each term, the first 10 links provided by both search engines were analysed. Paid links (adverts) were omitted from the research. Researched topics and searched information were in the Czech language only. To identify the most viewed websites, each link provided by a search engine was assigned points. The first Google Search link was assigned 20 points, and then each consecutive link was assigned two points less than the previous one (i.e. the second link was assigned 18 points, etc.). A similar ranking was used for Seznam.cz. However, the first Seznam.cz link was assigned 10 points only. The reason for a different scoring is the above mentioned different frequency of use of the two search engines in the Czech Republic. The decreasing value of assigned points reflects the finding that $21 \%$ of users click on the first link provided by a search engine. The second link is clicked by $11 \%$ of users, the third link by $8 \%$ of searchers, the fourth link by $5 \%$, and the remaining links follow the decreasing tendency ( $\mathrm{O}^{\prime}$ Leary, n.d.). Intriguingly, the most frequently searched word might mean two very different things in the Czech language. When a Czech user types "dna" into a search engine, they might either search for the gout disease or the deoxyribonucleic acid (DNA). Only links related to the gout disease were taken into account, links related to DNA were excluded. Thus a link on position 9 in Google Search leading to an article about DNA was assigned 0 points. The points assigned to individual websites displayed when searching 734 terms (diseases and symptoms) were summarised up to obtain a list of the most viewed websites, i.e. those with the greatest potential to influence Internet users in the Czech Republic searching for diseases and symptoms. These websites were then checked against the list of credible websites displayed on the MedLike portal as of 15th July 2019.

\section{Selection of Articles for Evaluation}

Articles for evaluation were to be selected based on the three most frequently searched terms (diseases and symptoms) on the six most frequently viewed sites (websites A - F). Since the most frequently searched term was the word "dna" (meaning both the gout disease and the deoxyribonucleic acid), it was likely that only some users searched for information about the disease. To offset possible discrepancies, the fourth most frequently searched term was added to the list of the criteria. Since the six most frequently visited websites were not on the MedLike list of credible websites, a website G (ranked seventeenth in our survey) was added for evaluation to compare the quality of the informa- 
tion also on a website listed in the MedLike credible sources list. The MedLike portal assesses quality in two stages. First, suitable resources are identified at a domain level, then specific articles of a particular website are evaluated. Although the supplementary website $G$ was identified as a suitable resource at a domain level, none of the articles related to four most frequently searched terms was recommended at the level of a particular website (using MedLike search according to topics). Thus, a website $\mathrm{H}$ was added (the most frequently visited websites for the second most frequently searched term - schizophrenia) which included a recommended article related only to the second most frequently searched term - schizophrenia.

\section{Defining Criteria for the Evaluation of Websites and Evaluation Procedure}

The evaluation was carried out in the period between July 2019 and January 2020 according to predetermined criteria, identical to the criteria selected for the article Internet - the threat or hope of Czech health literacy? (Pleskot, \& Rusová, 2018). These are criteria for assessing both content and form, such as the explanation of symptoms and diseases, etiology and pathogenesis, symptoms, diagnosis, differential diagnosis, treatment options, prevention and accuracy of facts in terms of evidence-based compliance, grammar and stylistics, readability (ie text clarity evaluated according to Mistrík's formula $R=50-S$ * $V$ * $L$ / $\mathrm{N}$, where $\mathrm{R}$ is readability, $\mathrm{S}$ is the average number of syllables in a word, $\mathrm{V}$ is the average number of words in a sentence, $L$ is the number of different words in the sample and $\mathrm{N}$ is the number of all words in the sample (Mistrík, 1968), presence and frequency of unexplained medical terms, the date of publication and last update, authorship, listing sources including their date of publication and quality, logical ordering of information and aesthetics. Individual sites were also evaluated for their purpose and ownership, presence of advertisement, third-party accreditation, personal data protection in case of registration, the possibility of interaction, charging, and the option of other languages. Additionally, the presence of a medical disclaimer (e.g. the information on the site cannot substitute for professional medical advice) was added as a criterion.

Given the subjectivity of some criteria, the assessment was carried out individually by the authors on their own and the findings consequently compared. Disagreement was solved by a discussion between the authors.

\section{RESULTS}

Out of the list of 7,753 health terms (diseases, symptoms, drugs/medications, herbs), the most frequently searched among the diseases and symptoms (734 terms) were the terms gout, schizophrenia, scabies, and shingles, see Table 1. As mentioned above, the term gout is somewhat problematic as there is no way to confirm whether a user really searched for the gout disease ("dna" in Czech) or the search was intended for information about deoxyribonucleic acid (DNA). However, due to recent changes in dietary recommendations concerning the 
Journal of Education Culture and Society No. 1_2020

gout disease, this term is useful for checking whether the websites include up-todate information. In the survey, the most frequently searched drug was Wobenzym and the most frequently searched herb was sea buckthorn.

Table 1.

The most frequently searched among the diseases and symptoms

\begin{tabular}{|c|c|c|c|c|c|c|}
\hline Rank & $\begin{array}{c}\text { Disease } \\
\text { Symptom }\end{array}$ & Ø 1Q 2018 & Ø 2Q 2018 & Ø 3Q 2018 & Ø 4Q 2018 & Ø 2018 \\
\hline 1 & Gout & 13278 & 13292 & 9896 & 14292 & 12689 \\
\hline 2 & Schizophrenia & 11641 & 11628 & 9206 & 14162 & 11659 \\
\hline 3 & Scabies & 10959 & 9108 & 9124 & 13828 & 10755 \\
\hline 4 & Shingles & 10157 & 10321 & 10863 & 10033 & 10344 \\
\hline 5 & Measles & 4257 & 24047 & 3902 & 4144 & 9088 \\
\hline 6 & Autism & 11118 & 11168 & 6253 & 7684 & 9056 \\
\hline 7 & Depression & 8516 & 8661 & 7464 & 8688 & 8332 \\
\hline 8 & Impetigo & 7106 & 6791 & 10154 & 7646 & 7924 \\
\hline 9 & Heartburn & 7615 & 6907 & 7135 & 8535 & 7548 \\
\hline 10 & Syphilis & 7790 & 7658 & 6751 & 7869 & 7517 \\
\hline 11 & Chlamydia & 7992 & 7953 & 6203 & 7688 & 7459 \\
\hline 12 & Hemorrhoids & 8013 & 6986 & 6502 & 6884 & 7096 \\
\hline 13 & Hordeolum & 7066 & 7502 & 6702 & 6449 & 6929 \\
\hline 14 & Crohn's disease & 4990 & 7924 & 7030 & 7513 & 6864 \\
\hline 15 & Angina & 7446 & 6576 & 5229 & 7941 & 6798 \\
\hline 16 & Diabetes & 7020 & 6877 & 5325 & 7467 & 6672 \\
\hline 17 & Wart & 6277 & 7148 & 6339 & 5508 & 6318 \\
\hline 18 & Laryngitis & 7024 & 3918 & 2902 & 10029 & 5968 \\
\hline 19 & Down's syndrome & 7679 & 6257 & 4479 & 5118 & 5883 \\
\hline 20 & Mumps & 8110 & 5663 & 3478 & 5123 & 5594 \\
\hline 21 & Celiac disease & 6599 & 5388 & 4421 & 5830 & 5559 \\
\hline 22 & Urinary tract infl. & 5165 & 4235 & 5818 & 5899 & 5279 \\
\hline 23 & Sore throat & 6104 & 4602 & 3753 & 5907 & 5092 \\
\hline 24 & Conjunctivitis & 5450 & 6248 & 3538 & 4430 & 4916 \\
\hline 25 & Roseola & 3779 & 5678 & 5547 & 4414 & 4855 \\
\hline 26 & Corn & 4728 & 5422 & 4421 & 4181 & 4688 \\
\hline 27 & Atopic exema & 5381 & 4623 & 3240 & 5093 & 4584 \\
\hline 28 & Cystic fibrosis & 6447 & 4170 & 2526 & 4573 & 4429 \\
\hline 29 & Burnout syndrome & 5473 & 4637 & 2923 & 4593 & 4407 \\
\hline 30 & Hemroids & 4060 & 4129 & 3629 & 3665 & 3871 \\
\hline
\end{tabular}

Source: created by the authors

Using the list of the searched terms among the diseases and symptoms (734 terms), the most frequently viewed health-related websites (and thus having the greatest potential to affect Internet users in the Czech Republic) were identified. Then, these were checked whether they are on the MedLike list of cre- 
dible websites and whether they include any verified articles on gout, schizophrenia, scabies, or shingles. Out of the top twenty websites, only 3 were credible - linkos.cz (ranked $\left.7^{\text {th }}\right)$, mou.cz $\left(16^{\text {th }}\right)$, and symptomy.cz (ranked $\left.17^{\text {th }}\right)$. However, none of the top twenty websites included an article on gout, schizophrenia, scabies, or shingles searchable by the MedLike portal, being verified using the criteria of the National Medical Library, see Table 2.

Table 2.

Websites with the greatest potential to affect Internet users in the Czech Republic

\begin{tabular}{llrlc}
\hline Rank & \multicolumn{1}{c}{ Web } & Score & $\begin{array}{c}\text { Presence on the } \\
\text { MedLike list of } \\
\text { credible websites }\end{array}$ & $\begin{array}{c}\text { Presence of verified } \\
\text { articles on gout/ } \\
\text { schizophrenia/ } \\
\text { scabies/shingles }\end{array}$ \\
\hline 1 & ulekare.cz (A) & 10794 & NO & NO \\
2 & mojezdravi.cz (B) & 9293 & NO & NO \\
3 & cs.wikipedia.org (C) & 7610 & NO & NO \\
4 & wikiskripta.eu (D) & 6322 & NO & NO \\
5 & vitalia.cz (E) & 3701 & NO & NO \\
6 & nemoci.vitalion.cz (F) & 2751 & NO & NO \\
7 & linkos.cz & 1993 & YES & NO \\
8 & cs.medixa.org & 1918 & NO & NO \\
9 & stefajir.cz & 1865 & NO & NO \\
10 & emimino.cz & 1840 & NO & NO \\
11 & ordinace.cz & 1508 & NO & NO \\
12 & anamneza.cz & 1433 & NO & NO \\
13 & novinky.cz & 1411 & NO & NO \\
14 & idnes.cz & 1400 & NO & NO \\
15 & zena-aktualne.cz & 1343 & NO & NO \\
16 & mou.cz & 1311 & YES & NO \\
17 & symptomy.cz (G) & 1229 & YES & NO \\
18 & zdravi.euro.cz & 1107 & NO & NO \\
19 & uzdravim.cz & 1055 & NO & NO \\
20 & rehabilitace.info & 823 & & \\
\hline
\end{tabular}

Source: created by the authors

To assess the impact of the MedLike portal, it was decided to review the first six most influential sites, along with two credible websites: symptom.cz and schizofrenie.psychoweb.cz, altogether 8 websites.

Individual websites were assessed according to predetermined criteria, see Table 3. Among these 8 websites, there were 6 popular educational websites, one open encyclopedia (cs.wikipedia.org - website C), and one learning portal run by First Faculty of Medicine, Charles University, Prague (wikiskripta.eu - website D). The last two mentioned are the only websites without advertisement and only web $\mathrm{C}$ having another language option. It was found that none 
of the websites was paid. The most serious finding is that two of the websites (website B and website E) do not display a medical disclaimer. The other four websites contain a medical disclaimer, however, it is not shown without looking for it (most articles on websites C, and A, D, and F). The medical disclaimer on website $\mathrm{H}$ is almost hidden in the text below a particular article. This fact is particularly alarming for website $B$, which contains information on alternative treatment (folk remedies, homeopathics).

Table 3.

Evaluation of the websites

\begin{tabular}{|c|c|c|c|c|c|c|c|c|}
\hline Criteria & Web A & Web B & Web C & Web D & Web E & Web F & WebG & Web H \\
\hline Purpose & edu & edu & $\begin{array}{l}\text { open } \\
\text { encyclo- } \\
\text { pedia }\end{array}$ & $\begin{array}{l}\text { learning } \\
\text { portal }\end{array}$ & edu & edu & edu & edu \\
\hline Ad presence & yes & yes & no & no & yes & yes & yes & yes \\
\hline Acreditation & no & no & no & no & no & no & yes & yes \\
\hline $\begin{array}{l}\text { Personal data } \\
\text { protection }\end{array}$ & yes & yes & yes & yes & yes & yes & no & yes \\
\hline Registration & yes & no & yes & $\begin{array}{l}\text { yes } \\
\text { (edit.) }\end{array}$ & yes & yes & no & no \\
\hline Charging & $\mathrm{no}^{* *}$ & no & no & no & no & no & no & no \\
\hline $\begin{array}{l}\text { Other } \\
\text { languages }\end{array}$ & no & no & yes & no & no & no & no & no \\
\hline Interaction & $\begin{array}{l}1 \\
2\end{array}$ & 3 & edit & 1 & 1 & $\begin{array}{l}1 \\
4\end{array}$ & $\begin{array}{l}1 \\
3\end{array}$ & 1 \\
\hline $\begin{array}{l}\text { Medical } \\
\text { disclaimer }\end{array}$ & yes ** & no * & yes & yes & no & yes & yes & yes \\
\hline Aesthetics & + & + & + & + & + & + & + & + \\
\hline
\end{tabular}

* in article on the gout disease, there is information that if the joints hurt, you need to see a doctor, ** only for counselling, 1 - e-mail, 2 - counselling, 3 - reader comments, 4 - discussion

Source: created by the authors

Specific articles for evaluation were selected based on the most frequently searched terms of disease and symptoms (gout, schizophrenia, scabies, and shingles) on the six most viewed/most influential sites, and on websites $G$ and $\mathrm{H}$. Website B only contained articles related to gout, scabies, and shingles, whereas website $\mathrm{H}$ contained an article related to schizophrenia only. Altogether 28 articles were evaluated on 8 websites.

The evaluation results are shown in Tables 4,5 and 6 .

\section{Evaluation of articles on website A}

The article on gout contains outdated information on a diet - it does not recommend legumes, and also eggs and coffee, whilst coffee can be considered a protective factor, especially in men $(\mathrm{Li}, \mathrm{Yu}, \& \mathrm{Li}, 2018)$. In the treatment of gout only colchicine is mentioned, although it is only one of the options of 
treatment, see Marta Olejárová (2017). The article on gout contains unexplained terms. There are grammar errors and typos both in the article on gout and the article on schizophrenia, both articles have a publication date (2008), without an update. None of the reviewed articles on website A has an author, but authors of some articles on shingles can be traced. No article displays its source. The readability ranges from moderately difficult text to expository text. The value of readability of the article on scabies is distorted because of the length of the text.

\section{Evaluation of articles on website B}

An article on the gout disease is the most controversial. When explaining the disease, the article omits a lot of important information, e.g. increased purine formation in tumours, renal function disorders, information on genetic factors and disorders, and information on drug-induced gout. From the clinical point of view, the distinction between hyperuricaemia and acute gouty attacks is important, since treatment to patients varies. An omission of this distinction in the article affects not only an explanation of the disease but also etiology, pathogenesis, and treatment. Website B states that gout occurs in children, which may be misleading without further explanation and in the absence of the above information. It is also wrong to state that gout: "most often affects men in their forties or women before menopause", as the disease rarely affects women before menopause (probably due to a protective effect of estrogens) (Dirken-Heukensfeldt, Teunissen, van de Lisdonk, \& Lagro-Janssen, 2010).

The article does not provide information on what (apart from diet) affects the recurrence of gouty attacks (infections, stressful situations, surgical procedures, diuretic use). A "strict diet" is recommended as treatment, but no risks of starvation are mentioned (Vachek et al., 2018). Information on a diet is not up-to-date as legumes and spinach are not recommended, although studies as early as 2004 (Choi, Atkinson, Karlson, \& Curhan, 2005) show that moderate intake of purine-rich vegetables does not increase the risk of gout as well as lentils and peas, which are an important source of protein (Li, Yu, \& Li, 2018; Choi, Atkinson, Karlson, \& Curhan, 2005). From the diagnosis only synovial fluid analysis and X-ray examinations are presented, laboratory examinations such as blood count, C-reactive protein test (CRP), erythrocyte sedimentation rate - Fähraeus-Westergen test (FW), uric acid levels (which may or may not be increased during a seizure) are missing (Vachek et al., 2018). The treatment lacks information on topical therapy, but gives advice on folk remedies, herbs and homeopathics, which is typical of this website, but definitely cannot be considered an evidence-based practice. Allopurinol is listed as a medication, which is a problem when not distinguishing acute gouty attacks from hyperuricaemia since allopurinol therapy must not be started at the time of the acute attack (Vachek et al., 2018). Articles on scabies and shingles are less problematic, however, the article on shingles contains controversial information about its contagiousness: "The contagious period is about 1-2 days before the first symptoms and a maximum of 5 days after the appearance of the blisters (after they dry up)". According to Cen- 
ters for Disease Control and Prevention (CDC), shingles are contagious only by direct contact with the blister fluid, and CDC explicitly states that a person is not contagious before the appearance of blisters (CDC, 2019). Articles on gout and shingles contain unexplained terms, there is no publication date or a date of update, none of the articles shows their author, and only the article on shingles has a source (just one and it dates back to 2008). The readability of articles varies between moderately difficult and expository text.

\section{Evaluation of articles on website $\mathrm{C}$}

Website C lacks certain options for therapy, namely electroconvulsive therapy in schizophrenia, and analgesic and local therapy in shingles. Also, it does not warn against fasting for gout. Some articles contain unexplained terms. There is no publication date for any of the articles, only an update date is displayed (2019), but this is not reflected in the list of literature. All articles have sources, but they are not always of high quality or up to date. The readability of texts ranges from expository to the edge of comprehensibility.

\section{Evaluation of articles on website D}

Similarly, this website contains outdated information on diet concerning gout and the article does not warn against fasting. The article on shingles does not mention analgesics, except for antidepressants and anticonvulsants for neuralgia treatment, there is also no information on supportive treatments such as regional anaesthesia or administration of vitamins, see Lucie Růžičková Jarešová (2015). Also, combining information on shingles with information on chickenpox in the overview table is very confusing. There are unexplained terms on all pages and there is no publication date, only an update date (2018-2019) is provided, but it is not reflected in the sources except for gout. Not all sources are of good quality. The readability of the shingles is distorted by the length of the text, other articles range from expository texts to texts difficult to understand.

\section{Evaluation of articles on website E}

The article on gout lacks information on increased purine formation in tumours and renal function disorders, genetic factors and disorders, and drug-induced gout. The article on shingles is the only article on this website that lists at least one source (Wikipedia). In the article on scabies, there is no description of the symptoms visible on the skin, only itching is mentioned. The article on schizophrenia does not adequately describe the treatment and there are unexplained terms. There is no publication date or authorship indicated for any articles. All readability calculations were distorted by the length of the text.

\section{Evaluation of articles on website $\mathbf{F}$}

Likewise, the article on gout lacks information on increased purine formation in tumours and renal function disorders, genetic factors and disorders, and drug-induced gout. Furthermore, information on X-ray diagnosis is missing and there is outdated information on diet (it prohibits legumes and spi- 
nach, coffee is allowed only in limited quantity), diet is recommended and the article does not warn against fasting.

Overwhelmingly, this website tends to promote alternative ways of treatment. The article on schizophrenia lacks information on the dangers of drugs and the text on shingles lacks information on vaccination. Controversial or even erroneous information occurs in the article on schizophrenia: "we can prevent the occurrence of schizophrenia by a healthy lifestyle ..." Dubious terms are used e.g. "neuroseptic hypotension".

Another article containing incorrect information is the text on shingles. It claims that "After curing this disease, the virus does not return. Twice is enough." However, the opposite is true - shingles can occur repeatedly (CDC, 2019). Similarly, to website B, the information on its contagiousness is both incorrect and inconsistent: "The contagious period is about 1-2 days before the first symptoms and a maximum of 5 days after the appearance of the blisters (after they dry up)".

There are unexplained terms for schizophrenia and scabies. No articles contain publication dates, updates, author information, or resources. The texts are mostly expository, only the article on schizophrenia is a text difficult to understand.

\section{Evaluation of articles on website $G$}

This website is the only one listed on the MedLike list of credible websites (by June 2019). However, the article on gout again lacks information on increased body purine formation in tumours and renal function disorders, information on genetic factors and disorders, and drug-induced gout. The article on scabies presents some controversial information. According to the author, the most common way of transmission of scabies is among sexual partners. Also, the author uses fallacies:

So far, scabies has been considered a disease occurring exclusively in homeless people and people living in similar circumstances. Recently, the disease has been thriving in young adults too. It is generally pointed out that the disease is often confused with eczema, so it often remains unnoticed and neglected.

- all this information is presented without a single reference. All articles lack information on differential diagnosis, and articles on gout and schizophrenia miss diagnosis completely. Articles on gout and shingles contain unexplained terms. There is no publication or update date for any article, and all articles lack sources. Only articles on schizophrenia and shingles indicate their authors. Most texts are expository, except for the article on gout, which has an average difficulty.

\section{Evaluation of articles on website $\mathbf{H}$}

On this website, there is only an article on schizophrenia. This article can be found on the MedLike portal. Genetic factors, diagnostics, and differential diagnostics are not mentioned in the article, and also, there are unexplained terms and typos. There is no publication date or a date of an update. The author is credited, but the article does not list any sources. The text is difficult to understand. 
Journal of Education Culture and Society No. 1_2020

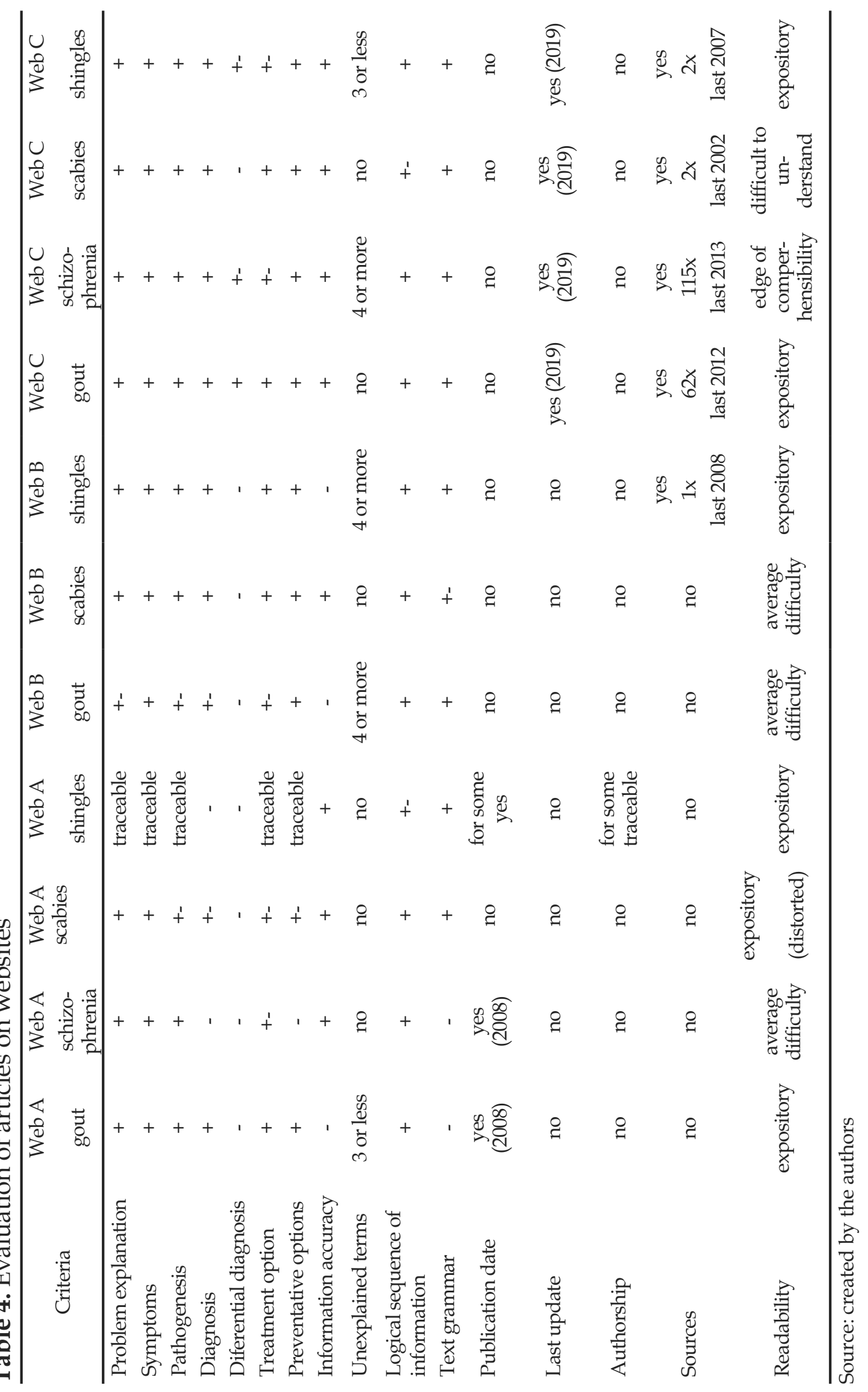


Journal of Education Culture and Society No. 1_2020

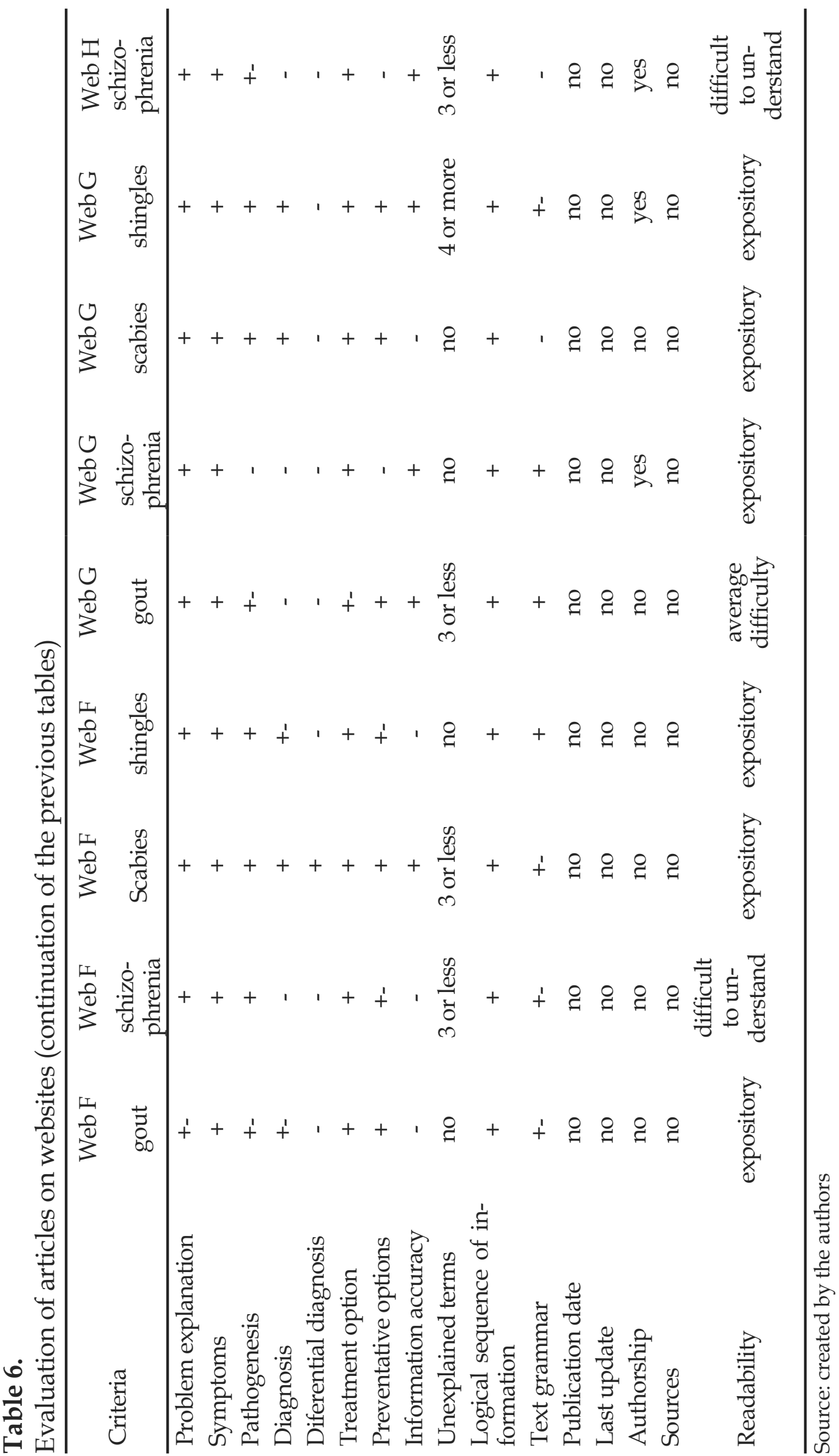




\section{DISCUSSION}

There are many different criteria applicable to assessing the quality of information sources, including the Internet. The criteria for the purposes of this survey were established on the basis of a review article by Yan Zhang, Yalin Sun, and Bo Xie (2015) and the Food and Agriculture Organization of the United Nations (FAO) Web Quality Assurance Checklist (2011). These were consequently complemented by other criteria such as the usefulness of information for prevention, differential diagnosis alerts, the presence and number of unexplained medical terms, readability, and last but not least, a medical disclaimer. Mistrík's formula was used to evaluate readability (comprehensibility) of the texts (Mistrík, 1968).

The assessment of readability showed that none of the texts was easy to understand. The best results were obtained by the texts on website $B$, where out of three of the evaluated articles two had an average difficulty and one was ranked as expository, ie demanding but understandable. The article on schizophrenia on website $\mathrm{C}$ was the only one rated as a text on the edge of comprehensibility, even as incomprehensible. Also, in the Henna Kim and Bo Xie survey (2017), Wikipedia was the most difficult to understand, while being the most viewed website in their survey. As far as our research is concerned, it was the schizophrenia texts that were the worst of all in terms of readability. Poor clarity, along with unexplained medical terms that occurred in more than half of the articles reviewed (15 out of 28 ), reduces the likelihood of understanding information, especially in individuals with lower health literacy.

The difficulty of texts available on the Internet was pointed out also by Elad Yom-Tov, Barbara Marino, Jennifer Pai, Dawn Harris and Michael Wolf (2016), who reviewed texts on diabetes mellitus and found that the required reading level is high and that more than $80 \%$ of the information requires a seventh or higher level. The clarity of the texts in the field of oral cavity cancer information was examined by Pablo Varela-Centelles, Yanina Ledesma-Ludi, Juan Manuel Seoane-Romero, and Juan Seoane (2015) with similar results - the texts were difficult to understand. Keonho Albert Kong and Amanda Hu (2015) also examined the readability of the texts, in their case, in the field of tracheostomy care. They found that the information available online was more difficult than levels 4 to 6 levels which are usually recommended for written health information. It was also found that information on websites dedicated to professionals was more difficult to understand than information websites for patients. Only one of the websites in our survey was not focused on lay public (website D, which is the educational portal of the First Faculty of Medicine). However, the readability of the articles contained therein was comparable in difficulty to the articles on popular educational websites.

Some evaluated websites (especially website B) contained information on alternative practices, such as folk remedies, use of herbs and homeopathics, which is out of the scope of the evidence-based medicine. A medical disclaimer 
was totally missing in websites $\mathrm{B}$ and $\mathrm{E}$, and not clearly displayed for most articles on website $\mathrm{C}$, and websites $\mathrm{A}, \mathrm{D}$, and F. This is alarming, alongside with the findings that some information was outdated or even incorrect.

Nonetheless, the dangers of poor quality health information available on the Internet have been pilloried for over 20 years. Gretchen P. Purcell, Petra Wilson and Tony Delamothe (2002) jokingly pointed out that no matter what topic we choose, we are likely to achieve the same results as P. Impicciatore et al. who studied information on the treatment of fever in children and found that information available varied greatly in accuracy, completeness, and consistency. Our survey confirmed these findings. In our survey articles varied in quality even within one website.

Problems with outdated information were associated mainly with dietary restrictions in case of gout. The only website providing updated information was website C. As website D is an educational portal of the First Faculty of Medicine, the absence of updated recommendations is surprising.

Another serious finding concerns information on shingles, where two websites (website B and website F) display incorrect information regarding contagiousness, and website $\mathrm{F}$ adds a false statement about a possible relapse. And so it may not be surprising that it is again website F, where we can find incorrect and misleading information on schizophrenia. The claim that "the emergence of schizophrenia can be prevented by a healthy lifestyle..." is comparable to the false hopes that Alla Keselman, Catherine Arnott Smith, Anita C. Murcko and David R. Kaufman (2019) found in "nonevidence-based" websites dedicated to type 2 diabetes where 14 out of 25 websites contained a promise of complete recovery, or at least strongly suggested that a complete recovery was highly likely.

A. Keselman, C. A. Smith, A. C. Murcko and D. R. Kaufman (2019) also point out the issue of unverifiable information. They found that 20 out of the 25 websites in their study contained an unquoted reference to studies and data that could not be searched, as was the case with scabies on website $G$ in our survey. However, there is a surprising difference in the number of sites that have a date of publication or the date of the update. In A. Keselman, C. A. Smith, A. C. Murcko and D. R. Kaufman (2019), such information was available in 21 out of the 25 sites reviewed. In our case, the date of publication was available only in 2 out of the 28 sites reviewed and the date of update date in 8 of them. The question arises whether the character of the sites under consideration can play a role in this, as in our survey these were in most cases popular educational sites. Similarly surprising is the comparison of the availability of information about the authors of the websites under review. In the study of A. Keselman, C. A. Smith, A. C. Murcko and D. R. Kaufman (2019), information on authors was available on most sites. Our survey only found 3 out of the 28 websites. This was also the most obvious difference between websites which were approved by MedLike and those which were not. Information on authors was available on website $G$, which is on MedLike list of credible websites, and also website $\mathrm{H}$, whose article had a link on MedLike portal. 
To assess the impact of MedLike portal, initiated by the National Medical Library, in more detail, we have to reflect possible differences in the criteria used. MedLike portal evaluates the quality of information sources in two phases - first, a suitable resource is identified at the domain level, and then the articles are assessed according to the following 8 criteria - authorship (assessing whether the author is an expert or whether the text was peer-reviewed), ownership (whether the owner of the website or the publisher is credible), currency of information (date of publication or of an update, but also links to resources and their quality and credibility), personal data protection, complementarity of information (whether the content is related to the purpose of the website), transparency (page financing, separation of advertisement from content, information related to the sale of goods), user-friendliness (easy navigation, clarity and accurate information) and verifiability of resources (NML, 2018-2020). Although the overlap is considerable, some of the criteria of our survey are not used by the National Medical Library, namely a presence of a medical disclaimer or assessing the usefulness of information in prevention. However, MedLike also includes documents that do not meet all the criteria, but are considered to be informative (NML, 2018-2010). This is confusing as it is not possible to find out which criteria a particular document or a website meets and which does not, and thus making an assessment of the conformity or the fulfilment of common criteria impossible. In addition to the information on authors, mentioned above, the websites and articles recommended by the National Medical Library clearly display a medical disclaimer without having to click through the website to find it. Nonetheless, as far as the correctness of the information on these verified websites is concerned, it was not without problems, as can be seen from the evaluation of information on scabies on website $G$.

\section{LIMITATIONS OF THE STUDY}

One of the limits of our study is the list of terms (illnesses, symptoms, drugs/medications, and herbs) which is not standardised and contains different variants, including spelling variants, and also commonly misspelt terms (e.g. "hemroids" for "hemorrhoids"). Thus, the list does not correspond to any standard classification (e.g. international classification of diseases). However, it reflects key words lay public uses in their Internet searches. As a result, we worked with terms which are missing on MedLike portal, as the National Medical Library classifies topics according to the International Classification of Diseases of the Statistical yearbooks published by Institute of Health Information and Statistic of the Czech Republic and European Health Interview Survey (EHIS) 2014 (Lesenková, 2016).

The problems in assessing search frequency the term gout has already been mentioned above. We are not able to tell whether the term gout has the highest number of searches due to the fact users frequently searched for DNA, or whether gout was indeed searched so frequently. In any case, in the 
vast majority of cases, internet search engines linked to websites dealing with gout, not DNA.

\section{CONCLUSION}

Out of the list of 7,753 health terms (diseases, symptoms, drugs/medications, herbs), the most frequently searched terms were gout, schizophrenia, scabies, and shingles in the category of diseases and symptoms, Wobenzym in the category of drugs and medications, and sea buckthorn in the category of herbs. The websites with the greatest potential to influence Czech Internet users in terms of health information are ulekare.cz, mojezdravi.cz, cs.wikipedia.org, wikiskripta.eu, vitalia.cz, and nemoci.vitalion.cz. Out of twenty most influential websites, only three are accredited by a third party (always by the National Medical Library).

When assessing the websites with the greatest potential to influence Internet users in the Czech Republic (complemented by symptomy.cz and schizofrenie.psychoweb.cz websites that have passed the National Medical Library quality assessment), it was found that these websites are predominantly (6 out of 8) popular educational websites. Most of them lack links to resources, information about the authors of the texts as well as dates of publication or updates. As a serious finding can be considered the fact that a medical disclaimer is totally missing in 2 websites, while other websites (with one exception) either do not display a medical disclaimer without a necessity to click through the website or a medical disclaimer is obscured in the text. None of the examined texts can be described as easy to understand and read, and many articles contain unexplained medical terms.

The most problematic was the evaluation of the quality of information regarding gout where a vast majority of websites lacked information relevant to clinical practice, such as updated information on dietary measures. Updated information on this issue was found on the website $C$ only (cs.wikipedia.org). Incorrect and misleading information was also found in the articles on shingles and schizophrenia. It can be conclusively stated that the worst state of the accuracy of information was found on website $\mathrm{F}$ (nemoci.vitalion.cz). 


\section{REFERENCES}

[1] CDC_Centers for Disease Control and Prevention (2019). Shingles (Herpes Zoster)_Transmission. Retrieved January 15, 2020, from https://www.cdc.gov/shingles/about/transmission.html.

[2] Černá, Z., \& Černý, M. (2011). Principy vyhledávání informací na internetu [Principles of searching information on the Internet]. RVP metodický portal inspirace a zkušenosti učitelü. Retrieved July 20, 2019, from https://clanky.rvp.cz/clanek/s/G/14533/PRINCIPY-VYHLEDAVANI-INFORMACI-NA-INTERNETU.html/.

[3] Dirken-Heukensfeldt, K. J., Teunissen, T. A., van de Lisdonk, H., \& Lagro-Janssen, A. L. (2010). Clinical features of women with gout arthritis. A systematic review. Clin Rheumatol, 29(6), 575-82.

[4] Diviani, N., van den Putte, B., Meppelink, C. S., \& van Weert, J. C. (2016). Exploring the role of health literacy in the evaluation of online health information: Insights from a mixed-methods study. Patient Educ Couns, 99, 1017-25.

[5] FAO_Food and Agriculture Organization of the United Nations (2011). FAO web quality assurance checklist - WACENT criteria for evaluating and monitoring web quality version 1.3. Retrieved January 15, 2020, from http://www.fao.org/fileadmin/user_upload/gmfp/docs/WebQualityAssuranceChecklist.pdf.

[6] Choi, H. K., Atkinson, K., Karlson, E. W., \& Curhan, G. (2005). Obesity, weight change, hypertension, diuretic use, and risk of gout in men: the health professionals follow-up study. Arch Intern Med, 11, 165(7), 742-8.

[7] Impicciatore, P., Pandolfini, C., Casella, N., \& Bonati, M. (1997). Reliability of health information for the public on the world wide web: systematic survey of advice on managing fever in children at home. BMJ, 314, 1875-9.

[8] Keselman, A., Arnott Smith, C., Murcko, A. C., \& Kaufman, D. R. (2019). Evaluating the Quality of Health Information in a Changing Digital Ecosystem. J Med Internet Res, 21(2), 11129. Retrieved January 15, 2020, from https://www.ncbi.nlm.nih.gov/pmc/articles/ PMC6384537/.

[9] Kim, H., \& Xie, B. (2017). Health literacy in the eHealth era: A systematic review of the literature. Patient Educ Couns,100(6), 1073-1082.

[10] Kong, K.A., \& Hu, A. (2015). Readability assessment of online tracheostomy care resources. Otolaryngol Head Neck Surg, 152(2), 272-278.

[11] Kučera, Z., Pelikan, J., \& Šteflová, A. (2016). Zdravotní gramotnost obyvatel ČR - výsledky komparativního reprezentativního šetření [Health literacy of the Czech population - results of a comparative representative survey]. Čas. Lék. Čes, 155, 233-41.

[12] Lesenková, E. (2016). Podpora zdravotní gramotnosti a knihovny [Health literacy and library support]. Časopis pro knihovny a informační střediska ve zdravotnictú, 21, 3-4.

[13] Li, R., Yu, K., \& Li, C. (2018). Dietary factors and risk of gout and hyperuricemia: a metaanalysis and systematic review. Asia Pac J Clin Nutr, 27(6), 1344-1356.

[14] Maixnerová, L., Křǐž, F., Mašková, K., Valdmanová, E., Lesenková, E. S., \& Burský, O. (2019). Technologické řešení a pracovní postupy při vytváření portálu MedLike [Technology solution and workflows for creating MedLike portal]. Knihovny současnosti 2019. Olomouc: SDRU_K. Retrieved January 15, 2020, from http://sdruk.mlp.cz/data/xinha/sdruk/2019/KKS2019/ Sbornik_KKS19.pdf.

[15] Mistrík, J. (1968). Meranie zrozumitel'nosti prehovoru [Measurement of speech clarity]. Slovenská řeč, 33(3), 171-8.

[16] NML_National Medical Library (2018-2020). MedLike. Retrieved January 30, 2020, from https://www.medvik.cz/medlike/.

[17] O'Leary, D. (n.d.). Announcing: 2017. Google search click through rate study. Retrieved July 20, 2019, from https://www.internetmarketingninjas.com/blog/google/announcing-2017-click-rate-study/.

[18] Olejárová, M. (2017). Kolchicin [Colchicine]. Remedia, 27(1), 22-26.

[19] Parvizi, M., Talai, N. N., \& Parvizi, Z. (2017). Quality of healthcare information on the Internet: the case of Apicectomies. Oral Surgery, 10, 35-39. Retrieved January 15, 2020, from https:// onlinelibrary.wiley.com/doi/abs/10.1111/ors.12263.

[20] Pleskot, O., \& Rusová, J. (2018) Internet - The threat or hope of Czech health literacy? Kontakt, 20(4), e424-e431. Retrieved January 15, 2020, from https:/ / kont.zsf.jcu.cz/artkey/knt-201804- 
0017_internet-hrozba-nebo-nadeje-ceske-zdravotni-gramotnosti.php.

[21] Purcell, G. P., Wilson, P., \& Delamothe, T. (2002). The quality of health information on the internet. BMJ, 324, 557-8.

[22] Růžičková Jarešová, L. (2015). Varicella, herpes zoster, komplikace a postherpetické neuralgie, prevence [Varicella, herpes zoster, complications and postherpetic neuralgia, prevention]. Neurol. praxi, 16(5), 290-292.

[23] TOPlist s. r. o. (1997-2018). TOPlist-globální statistiky [TOPlist - global statistic]. Retrieved July 20, 2019, from www.toplist.cz/global/.

[24] Turan, N. Kaya, N. \& Aydin, G. Ö. (2015). Health Problems and Help Seeking Behavior at the Internet. Procedia - Social and Behavioral Sciences, 195, 1679-82.

[25] Vachek, J., Motán̆, V., Zakiyanov, O., Hrnčiř́íková, A. Motáň, J., Ciferská, H., \& Tesař, V. (2018). Akutní stavy ve vnitřním lékařství [Acute conditions in internal medicine]. Praha: Maxdorf.

[26] Varela-Centelles, P., Ledesma-Ludia, Y., Seoane-Romeroa, J. M., \& Seoane, J. (2015). Information about oral cancer on the Internet: our patients cannot understand it. British Journal of Oral and Maxillofacial Surgery, 53(4), 393-395.

[27] Yom-Tov, E., Marino, B., Pai, J., Harris, D., \& Wolf, M. (2016). The Effect of Limited Health Literacy on How Internet Users Learn About Diabetes. J Health Commun, 21(10), 1107-14.

[28] Zhang, Y., Sun, Y., \& Xie, B. (2015). Quality of Health Information for Consumers on the Web: A Systematic Review of Indicators, Criteria, Tools, and Evaluation Results. J Assoc Inform Sci Technol, 6(10), 2071-84. 